\title{
Problems of regional management of innovative food industry development
}

\author{
Ludmila Kilimova ${ }^{1}$, Olga Nishnianidze ${ }^{1}$, Michael Cherkashin ${ }^{1}$, and Alexey Pykhtin ${ }^{1}$ \\ ${ }^{1}$ Southwest State University, 305040, Kursk, 50 Let Oktyabrya Street, 94
}

\begin{abstract}
The article describes the need to consider management of innovative food industry development at all levels of national economy. Management of innovative potential of regional economic entities is considered as a set of processes and activities of management cycle, forms, and methods of its organization, aimed at ensuring innovative development of economic entities, achieving formulated mission and innovative goals using a focused impact on innovative potential components.

Organizational structure of state management of innovative potential is also described. Horizontalvertical structure of innovative potential management of regional economic entities of Russian food industry is based on this structure. It is described in the context of all levels of national economy. Innovative potential of regional economic entities is managed according to the principle of complexity, systemicity, goal commitment and continuality. A resource-based approach has been identified for innovation capacity management process.
\end{abstract}

Keywords: food industry, enterprises of food industry, innovation, innovative activity, innovative policy, regional entities of management, innovative development, management of innovative development.

\section{Introduction}

Food independence has become particularly relevant in conditions of unfavourable political environment of recent years. However, its solution comes across several serious problems. First of all:

- insufficient agricultural raw materials meeting the requirements of modern production. In turn this leads to huge losses of fruits and vegetables, as well as deep import dependence;

- significant equipment deterioration, compounded by the absence of some processing facilities;

- unwillingness of producers to increase competitiveness level of their products;

- weak infrastructure for food transportation and storage;

- lack of adequate solution level of environmental problems emerging;

- price volatility of food commodity.

- personnel problems caused by low wages and absence of vocational training system that meets the requirements of our time.

Food industry development of the Russian Federation was influenced by the crisis caused by 2020-2021 coronavirus pandemic, which had both negative and certain positive impact, primarily associated with irrational, sometimes hype demand for certain groups of food products. The main problems of food industry development of the Russian Federation during the pandemic crisis are associated both with a reduction in volume of solvent demand, primarily from relatively low- income segments of the population, and with restrictions on financial and investment plan. The latter are:

- a sharp reduction in previously planned investment development programs of most domestic food production in 2020;

- reduced availability of credit resources for domestic food industry organizations, primarily of long-term storage;

- intensity reduction of regional clusters formation of food industry [Feoktistov, 2020, p. 34-39].

However, processes of finding and introducing innovations have intensified in pandemic, which gives a chance to bring food processing and production to a new level. As a result, economic environment to which food industry get used has lost its relevance. And manufacturers must change quickly and comprehensively for their survival. The one who cannot do this is likely to remain on "sidelines". Transition to new technologies experts call as one of the ways of such adaptation. This is, first of all, active automation of production processes. Innovative transformations help to increase the efficiency of enterprises in any economic sector, including the agricultural sector and the food industry. [Obukhova A.S., Kolmykova T.S., Klykova S.V. Mashegov P.N. et al., 2021; Sakhno A., Salkova I., Broyaka A., Priamukhina N., 2019; Fedotova G.V., Gorlov I.F., Glushchenko A.V., Slozhenkina M.I. et al., 2020].

Innovation activities have risk features since elements of uncertainty significantly affect innovative development. This happens despite significant resource, technological and scientific potential in Russia.

Decision-making in uncertain environments is based on factors that do not always have quantitative 
dimensions, and managers often rely on their experience and intuition. However, it may happen that some factor with a low degree of influence is able to have a significant cumulative effect through its indirect interaction with other factors. Decision-making in conditions of uncertainty and study of causal links between indicators of production system allows considering probabilistic ideas about possible production situations.

Unresolved parts of overall issue of strategic innovation management include the development of directions and priorities for innovative enterprise development through the introduction of new strategic management tools and mechanisms at regional level.

\section{Research methods}

General scientific methods were used to solve set tasks of scientific research. These methods are generalization - to analyze views of scientists regarding object of the study and formulate proposals and conclusions of the content analysis of primary sources; analysis and synthesis - to clarify main concepts involved in the article. special methods of scientific knowledge were used: formallogical - to form a method for choosing a strategy for the development of economic entities; statistical, comparative analysis - to assess the current state of innovation and trends in the formation of innovative potential of food industry in regional aspect.

\section{Results and discussion}

Management of innovative potential in food industry is quite heterogeneous in regions of our state, as it depends on internal properties and capabilities of each region. Effective governance of innovation capacity at the state level therefore requires autonomy in addressing a wide range of innovation issues at regional level. It is also important to promote successful cooperation between regions.

In developed world, innovation management system is based on interaction of national and regional management entity. At the same time, competencies of regional level include formation of lower and secondary levels of education, the development of business incubators, clusters, and innovation centers [Bigliardi B., Ferraro G., Filippelli S., Galati F., 2020].

National level deals with issues related to activities of universities, research, and innovation financing, as well as identifying priority areas for the development of the state. Decentralization involves transfer of authority from national level to regional or local level, as well as the delegation of certain responsibilities to mediation organizations, which are mainly public.

It should be noted that local state administrations and local governments in innovation sphere can involve enterprises, institutions and organizations located in their territory, with their consent, to solve problems of innovative development of regions, as well as provide financial support for innovative projects and programs within regional, district and local budgets funds.
However, there are many significant obstacles for local authorities to influence regional innovation development properly. Russia has successfully implemented reforms to decentralize power. Now Russia is a centralized state with high level of power concentration in the capital city. Therefore, local governments do not have sufficient finance and clear regulations to manage innovation capacity effectively.

In particular, the following factors impede innovation development in Russia:

- low degree of innovative activity of economic entities, their readiness to create new ideas, expenses in research development;

- weak legal and regulatory framework for the development and promotion of innovative processes;

- imperfect, insufficiently fully developed innovative infrastructure;

- low degree of cooperation within the framework of "education-science-business-state";

- lack of confidence in the effectiveness of state regulation methods, etc.;

- lack of investment in innovation, lack of venture capital, unsustainable processes of interests' protection, especially for foreign investors;

- high level of competition in national market and difficulty of exit, holding positions in international market.

In Russia, elements of a state with a resource-oriented economy prevail, which affects the difficulty of switching to an innovative scenario for national economy development, types of economic activities and economic entities. Such aspects make it difficult to find competitive advantages in markets, manage innovative development and potential, adjust strategic development directions of innovation, and produce optimal mechanisms for innovation strategy implementation.

It can be postulated that the formation of regional innovation system is currently at an initial stage of development. Its organizational elements operate independently of each other. Innovation infrastructure needs to be improved because it does not implement a significant part of functions that determine innovation effectiveness.

Analyzing the structure of national innovation system, it should be noted that when achieving regional innovation policy performance, a double dilemma arises. The first dilemma is rather theoretical, since most theories, concepts and studies remain rather vague. There is no generalization of effective concepts based on regional experience [Moulaert F., 2003, p. 253-254].

The second dilemma is that an effective innovation policy model of one region is used as a source for the development of another, without considering all its specific economic, financial and resource conditions [Hassink R., 2007, p. 290-292].

In this regard, it is necessary to share the experience of participants in innovative processes, which will allow the use of supporting tools and methods that will make it possible to make effective decisions, to avoid inaccurate conclusions that are inherent in many regional theoretical concepts. The use of assessment, regional forecasting, testing, and training should become important directions 
in solving this issue [Bigliardi, B., Galati, F., Pavesi, F. (2019)].

Management of innovative capacity of food processing enterprises at regional level depends on many economic, geological, geographical, and social factors of each region. It is necessary to consider all internal characteristics of the region, its capabilities and specificity, structure of regional authorities' activity to create an effective management system. In addition, it is important that, on the one hand, regional authorities have autonomy in dealing with issues related to innovation, and on the other, they successfully cooperate with other regions, central and state authorities, as well as economic entities to implement effective innovation policies.

In the process of innovative potential management of regional entities of food industry, it is important to conduct an expanded SWOT analysis of innovation activities, which provides for parallel research of both the individual object that is being introduced by the entity (technological innovations) and the economic unit, as a holistic social and economic system (entities of food industry). Such analysis will allow to cover and reveal the strengths and weaknesses of innovation implementation, opportunities, and threats to the business entity more comprehensively.

Management of innovative potential of regional economic entities in food industry should be carried out on the basis of organizational model of management entities. At the same time, this process should be included in the model of management process of innovative development at meso- and macroeconomic level, which contributes to the improvement of institutional innovation structures functioning, the development of innovative development transfer, and the establishment of interaction among all entities in the innovation process.

Production of food products from environmentally friendly raw materials is one of the most promising areas of innovative development of food industry. Organic agriculture is a production system that supports soil fertility, the quality of ecosystems and human health. Production of agricultural products according to the established rules allows you to produce organic products with wellness qualities, as well as preserve and introduce natural resources. Such products do not contain chemicals, antibiotics, preservatives, genetically modified organisms. Organic products should be grown without use of mineral and synthetic fertilizers and plant protection agents.

Developed countries of the world are implementing their quality standards and it is necessary to compile them. In EU countries, public authorities are authorized to accredit and monitor private certification institutions. They control farms, their products, monitor imports from other countries. In Russia, manufacturers sometimes use self-developed technical conditions instead of quality standards. The problem of organic agriculture is now gaining great attention for researchers. Natural conditions of the country are the basis for this.

There is a tendency to fill domestic market with its own organic products by establishing organic raw materials processing. Innovative directions in this matter are the production of fruit and vegetable conservation, baby food, dairy products. Profitability of such a business around the world depends significantly on the level of government support.

Mechanism for managing innovative development of the region should be considered as an orderly set of institutional frameworks that will ensure that economic entities achieve strategic guidelines for regional development [Kutsenko, 2014, p. 112]. Economic mechanism for managing innovative development of food industry enterprises at regional level should be focused on financing, material and labor support for novelty in the production of consumer goods, labor organization, and marketing services. In an innovation strategy based on the development of novelty in technology and the product produced, it is important to subordinate this mechanism to production cost reduction, ahead of this decrease dynamics in its competitors. At the same time, a line should be maintained to replace assortment and improve products' quality of food industry enterprises.

Quality-produced innovative products provide an enterprise sales volume and accordingly, income and a positive financial result at moderate prices. In order to ensure the development of food industry, which is based on innovation, it is necessary to meet the needs of customers and consumers by using innovative potential. We consider it appropriate to motivate an organization, to plan and control quality of innovative products using methods and levers of management.

Mechanism of innovative development management will provide food industry enterprise with increased competitiveness only in order in which all components of the mechanism are interconnected and work in a coherent manner, taking into account goals of innovative development. Main goals of an enterprise can be achieved only with the correct and rational use of all components of an economic mechanism for managing innovative development and considering the impact of economic laws [Ziablov, 2016].

It should be noted that an enterprise develops on the basis of an innovative strategy only when there are effective innovations. We believe that the efficiency of innovation is a positive result from the introduction into production process of newly created or already used and improved competitive processes, technologies, products, or services that have new properties or provide the possibility of using new technological processes, as well as organizational and technical solutions such as production, administrative, commercial or others, and is the result of scientific and technological progress.

Effectiveness of innovation is determined by its specific ability to create products that retain an appropriate amount of labor, time, material and technical resources, funds per unit of all necessary and envisaged useful effects of products, services, technical systems or allow increasing the production of tools, consumer goods that create comfortable living conditions for people and new rules of social relations.

In addition, the spread of innovation creates new knowledge and new information. New social knowledge accumulation in the society affects the pace of its development in the direction of changing trends in quality and lifestyle, increases the level of education, culture, 
intellectuality of the nation, thereby increasing innovative potential of the state.

Proliferation of innovations in food industry of Russian regions creates a set of positive effects that affect society development. Resource, economic, sociopolitical, environmental, scientific, and technical are among such effects.

Socio-political effect is the result, which contributes to the society development, satisfying its needs, and is evaluated mainly by qualitative indicators, for example, improving health, increasing the level of human intellectuality, democracy developing, education, satisfying aesthetic needs, etc. [Nishnianidze and etc., 2019]. A high level of quality of life from working conditions, living conditions, recreation, services, education, health care to political rights and freedoms, their inviolability [Kilimova, Lysikova, 2019] can contribute to meeting various needs.

As a rule, the more socio-political achievements, the more difficult it is to give them an integral quantitative assessment. Social assessments reflect contribution of the innovative project to improve social environment. So, improvement of life quality of people is characterized by the following indicators: standard of living; lifestyle; health and longevity.

Economic effect is the result of production development costs. Economic result is evaluated by a system of values and criteria. The latter are quite a lot: the cost of $\mathrm{R} \& \mathrm{D}$, investment in production, marketing, finance availability, potential annual profit, expected rate of return, total income for the entire life cycle of an innovation, absolute and relative efficiency. The most important indicator is absolute innovation effectiveness, which allows to evaluate each of them separately.

The environmental effect is the result of innovation interaction with the environment and is assessed using a system of relative indicators which characterize:

- reducing environmental damage (deforestation, water, soil and air pollution);

- integrated use of natural resources on the basis of waste-free production and reduction of their scarcity;

- reduction of industrial emissions into atmosphere, water, soil;

- reduction of production wastes quantity and possibility of their recycling;

- improving the level of environmental friendliness of products;

- improvement of goods' ergonomics (noise, vibration, electromagnetic radiation level);

- increasing liability and fines for violation of environmental legislation and other regulatory documents;

- environmental recreation [Rakhimov, 2018].

Scientific and technical effect is the result of scientific and applied developments and their use and can be estimated by an actual economic effect.

It is necessary to choose an adequate technological solution and appropriate level of organization and production apparatus for successful implementation of innovations.

Analysis of art and technology state requires not only and priority investigation, but also such important properties as adaptability under existing conditions, the ability to readjust the production apparatus. Flexibility is noteworthy characteristic of technology and organization.

In market space that is expanding in multiple diversifications, the pace of renewal is increasing, variety of product types and technologies which are necessary for their production are increasing. At the same time, goods, equipment and technology are at different stages of life cycle which belong to different models appear in production. In this regard, variability of technology and the need to adapt production management to these changes are sharply increasing.

\section{Conclusion}

With all these problems, food industry of Russian regions has significant development potential. Huge territories, labor availability, giant market with old traditions of high food consumption affect such development. Investment attractiveness in this market segment continues to be quite high.

The prospects for food industry development are in:

- formation of finished production chains in technological, and that is especially important, in financial. Enterprises must "feel" the order of consumers financially;

- attracting domestic and foreign investment;

- organization of large-scale reconstruction and construction of factories and industrial bases in order to achieve global level;

- increasing the processing depth of agricultural raw materials in order to avoid high losses;

- expanding trade and advertising;

- objective information of potential consumers about technological peculiarities of production, chemical content of products and specific terms of its storage. Moreover, buyer should have full access to relevant information in advance: before going to retail network.

Thus, in market conditions, enterprises of food industry of Russian regions are forced to apply innovative measures to increase competitiveness, which allows them to take a proper place in the economic space of the country. The results of innovation have positive impact on the state and functioning of both individual market entity and the state, which indicates effectiveness of innovation.

\section{Acknowledgements}

The publication was carried out within the framework of the state assignment for 2020 No. 0851-2020-0034

\section{References:}

1. A.A. Ziablov Econ.: yd, today, tomorrow Innovative development of food industry of Russia: opportunities and restrictions 2136 (2016)

2. E.I. Kutsenko Bull. of OGU Formation of a mechanism for managing innovative development of the region (on the example of Orenburg region) $\mathbf{1 4}$ (175) 110 (2014) 
3. O.O. Nishnianidze, M.D. Cherkashin, D.S Bogdanova. Proceed. of SWSU Ser: Econ. Soc. Manag. Social health as a socio-cultural phenomenon 95 (34) 197 (2019)

4. S. Rakhimova Int. J of Innov. Tech. in Econ. The role of innovation and the innovation process in the development of food industry 2 6(18) 15 (2018)

5. K.S. Fioktistov Prob. of econ. and manag. Problems of Russian food industry development in conditions of coronavirus pandemic 834 (2020)

6. B. Bigliardi, G. Ferraro, S. Filippelli, F. Galati J of Tech. Manag. \& Inn. Innovation Models in Food Industry: A Review of The Literature 153 (Santiago, oct. 2020)

7. B. Bigliardi, F. Galati, F. Pavesi How open is the food NPD process? Preliminary results from an explorative study Int. $\mathrm{j}$ of entrepreneurship and inn. Manag. 23(3) 229 (2019)

8. L. Kilimova, O. Lysikova Ekonomichnij chasopisXXI Health as a fundamental basis of population life quality 11-12 191(2019)

9. R. Hassink, R. Rutten, F. Boekema The Learn. Reg.: Found.s, St. of the Art, Future The learning region: $a$ constructive critique 252 (Cheltenham: Edward Elgar, 2007)

10. F. Moulaert, F. Sekia Reg. Stud Territorial Innovation Models: A Critical Survey 37289 (2003)

11. A.S. Obukhova, T.S. Kolmykova, S.V. Klykova P.N. Mashegov, A.G. Zaitsev, O.V. Popova E3S Web of Conf. Effic. Prod. and Proc. ICEPP-2021 Features and benefits of digital technologies in agricultural enterprises 24701018 (2021)

12. A. Sakhno, I. Salkova, A. Broyaka, N. Priamukhina Int. J of Rec. Tech. and Eng. (IJRTE) Methodology for the Impact Assessment of the Digital Economy on Agriculture Development 8160 (2019)

13. G.V Fedotova., I.F. Gorlov, A.V. Glushchenko, M.I Slozhenkina., A.K. Natyrov Dig. Econ.: Compl. and Var. vs. Ration. ISC 2019 Trends of Scientific and Technical Development of Agriculture in Russia $\mathbf{8 7}$ (Springer, Cham. 2020) 